\title{
Prolonged Glucocorticoid Exposure Reduces Hippocampal Neuron Number: Implications for Aging'
}

\author{
ROBERT M. SAPOLSKY, ${ }^{2}$ LEWIS C. KREY, AND BRUCE S. MCEWEN \\ Laboratory of Neuroendocrinology, The Rockefeller University, New York, New York 10021
}

\begin{abstract}
The hippocampus of the rat loses neurons with age, a loss which may eventuate in some of the functional impairments typical of senescence. Cumulative exposure to corticosterone (CORT) over the lifespan may be a cause of this neuronal loss, as it is prevented by adrenalectomy at mid-age. In this study, we demonstrate that prolonged exposure to CORT accelerates the process of cell loss. Rats were injected daily with sufficient CORT to produce prolonged elevations of circulating titers within the high physiological range. Animals treated for 3 months (chronic subjects) resembled aged rats in a number of ways. First, both groups had extensive and persistent depletions of CORT receptors in the hippocampus; in the case of chronic rats, no recovery of receptor concentrations occurred 4 months after the end of steroid treatment. Second, autoradiographic analysis revealed that the receptor depletion was due, in part, to a loss of CORT-concentrating cells, especially in the CA3 cell field. Remaining cells bound significantly less $\left[{ }^{3} \mathrm{H}\right]$ corticosterone than did those of control rats. Finally, analysis of size distributions of hippocampal cell bodies indicated that chronic subjects lost neurons of the same size as those lost in the aged hippocampus. Furthermore, chronic subjects also had increased numbers of small, darkly staining cells of CA3; these corresponded in size to the dark glia whose numbers increase in the aged hippocampus, and which are thought to infiltrate in response to neuronal damage or destruction. Thus, this study supports the hypothesis that cumulative exposure to CORT over the lifespan may contribute to age-related loss of neurons in the hippocampus, and that prolonged stress or exposure to CORT accelerates this process.
\end{abstract}

The hippocampus of the rat progressively loses corticosterone receptors (CORT-Rs) with age (Angelucci et al., 1980; Sapolsky et al., 1983a). A small CORT-R depletion is noted in the amygdala, but not in other brain regions or in the pituitary gland (Sapolsky et al., 1983a). The receptor loss is attributable to decreased concentrations of cytosolic CORT-Rs, with no change in receptor affinity or capacity for cell nuclear accumulation. The loss appears to be limited to neuronal receptors, with no change evident in the concentration of glial CORT-Rs (Sapolsky et al., 1983a), and is most dramatic among pyramidal neurons of the CA3 region (Sapolsky et al., 1984a). Finally,

Received: July 13, 1984; Revised November 5, 1984;

Accepted November 8, 1984

\footnotetext{
${ }^{1}$ This work was supported by a predoctoral grant from the National Institute on Aging to R. M. S.

${ }^{2}$ To whom correspondence should be sent, in care of the Peptide Biology Laboratory, Salk Institute, P. O. Box 85800, San Diego, CA 92138.
}

this hippocampal CORT-R depletion appears to be at least partially responsible for the dysfunctions of the adrenocortical axis in the aged rat (Sapolsky et al., 1984b).

We have searched for a means to correct the CORT-R deficit in the aged hippocampus. Alterations in the vasopressin content of the hippocampus have been reported to alter hippocampal CORTR concentrations (Veldhuis and de Kloet, 1982), and these appear to involve changes in the numbers of receptors per neuron (Sapolsky et al., 1984a). In contrast, the CORT-R depletion in the aged hippocampus appears to involve a loss of steroid-concentrating neurons (Sapolsky et al., 1984a). Thus, we are attempting to uncover the cause of the loss of hippocampal neurons with age.

We have considered the possibility that hippocampal neurons are lost due to cumulative exposure to glucocorticoids. Chronic exposure to stress or to elevated titers of corticosterone (CORT) downregulates CORT-Rs in an anatomical pattern identical to that seen in the aged rat (Sapolsky et al., 1984c). Furthermore, pharmacologic dosages of glucocorticoids reduce hippocampal neuron number (Aus Der Muhlen and Ockenfels, 1969). Finally, basal titers of CORT progressively rise with age (Landfield et al., 1978; Tang and Phillips, 1978; Sapolsky el al., 1983b; De Kosky et al., 1984), and adrenalectomy at 12 months can prevent the age-related loss of hippocampal neurons (Landfield, et al., 1981a). Thus, we designed the present studies to determine whether prolonged exposure to titers of CORT in the high physiological range would eventuate in the loss of CORTconcentrating neurons characteristic of the aged hippocampus. We present evidence for such a phenomenon and, in the following paper (Sapolsky, 1985), examine possible mechanisms by which glucocorticoids can be toxic to hippocampal neurons.

\section{Materials and Methods}

Subjects and treatments. Male Fischer 344 strain rats (Charles River Breeding Farms, Wilmington, Delaware) were utilized. Subjects were Caesarian-delivered and housed in pathogen-free colonies. All rats were given access to food and water ad libitum and were maintained on a $14 . / 10$-hr light/dark cycle (lights on: 6:00 A. M. to 8:00 P. M.). Subjects were injected subcutaneously daily with $5 \mathrm{mg}$ of CORT (Sigma Chemical Co., St. Louis, $\mathrm{MO}$ ) in $1 \mathrm{ml}$ of sesame oil. A single injection produced prolonged (minimum of $8 \mathrm{hr}$ ) elevations in circulating titers of CORT equivalent to those seen during stress (Table I). Short-term subjects (acute) received daily injections for 2 weeks. Long-term subjects (chronic) received injections for 3 months. Injections were terminated at that time because of a $50 \%$ mortality rate. Control subjects (CONT) received no CORT. All subjects were 8 months old at termination of treatment. Subjects were then used either for high resolution autoradiography of hippocampal CORT-Rs or for assays of hippocampal cytosolic CORT-Rs at various times following the end of treatment. Autoradiography was also conducted on untreated 28-month-old subjects, for use in comparisons with acute and chronic subjects.

Cytosolic CORT-R assays. Receptor concentrations were assayed either 2 days, 1 or 2 wccks, or 1,2 , or 4 months after the end of CORT treatment. Subjects were adrenalectomized and decapitated $12 \mathrm{hr}$ later. This time interval was used, rather than a 24-hour interval, because of the fragile health of some of the chronic subjects. Pairs of hippocampi (dorsal, ventral, and subiculum) were pooled and homogenized in $5 \mathrm{~mm}$ Tris buffer $(\mathrm{pH} 7.4)$ 
TABLE I

Efficacy of CORT injection in producing prolonged elevations of titers of CORT equivalent to stress-induced titers of the steroid (micrograms per $100 \mathrm{ml})$

\begin{tabular}{lccc}
\hline \multicolumn{1}{c}{ Treatment } & Basal & Stressed & Rise \\
\hline $\begin{array}{l}\text { Cage transter (30 min after } \\
\text { transfer) }\end{array}$ & $8.1 \pm 1.6$ & $15.2 \pm 3.1$ & +7.1 \\
$\begin{array}{l}\text { Cold exposure }(30 \mathrm{~min} \text { into } \\
\left.\quad \text { exposure to } 4^{\circ} \mathrm{C}\right)\end{array}$ & $7.2 \pm 1.3$ & $15.4 \pm 3.6$ & +8.2 \\
$\begin{array}{l}\text { Ether exposure }(20 \text { min after a } \\
\quad \text { 1-min exposure) }\end{array}$ & $3.9 \pm 0.9$ & $22.3 \pm 2.9$ & +18.4 \\
Histamine injection (20 min & $5.7 \pm 2.6$ & $15.8 \pm 2.9$ & +10.1
\end{tabular}
after i.v. injection of 1 $\mathrm{mg}$ )

CORT injection $(5 \mathrm{mg}$ in sesame oil) of adrenalectomized subjects

$0 \mathrm{hr}$ (pre-injection)

$4 \mathrm{hr}$

$<1 \mu \mathrm{g}$

$8 \mathrm{hr}$

17.2

12.8

$24 \mathrm{hr}$ 1.9

containing $1 \mathrm{~mm}$ EDTA, $10 \mathrm{~mm}$ sodium molybdate, $10 \%$ glycerol, and $1 \mathrm{~mm}$ dithiothreitol. The homogenate was centrifuged at $1^{\circ} \mathrm{C}$ for $30 \mathrm{~min}$ at 105,000 $\times g$. Aliquots $(250 \mu \mathrm{l})$ of cytosol were added to solutions containing various concentrations of $\left[{ }^{3} \mathrm{H}\right]$ dexamethasone $(5$ to $40 \mathrm{nM}$, as determined by direct counting of aliquots). Nonspecific binding was determined in parallel incubations which also contained a 500-fold excess of unlabeled CORT. Macromolecular bound steroid was isolated by chromatography on LH-20 columns, and eluates were counted in Liquiscint (National Diagnostics, Somerville, NJ) at an efficiency of $35 \%$. Cytosol protein concentrations were determined (Lowry et al., 1951) using bovine serum albumin (BSA) as a standard, and results were standardized as femtomoles of $\left[{ }^{3} \mathrm{H}\right]$ dexamethasone bound per milligram of cytosolic protein. Maximum binding $\left(B_{\text {rirax }}\right)$ and $K_{u}$ were derived by the method of Scatchard (1949).

Radioimmunoassay of corticosterone. Sera were separated after centrifugation and assayed for CORT by radioimmunoassay (Krey et al., 1975) using an antiserum generated against cortisol 21-succinate BSA (antisera F21-53, Endocrine Sciences, Tarzana, CA). This antiserum cross-reacts with CORT $(\sim 60 \%)$ but not with progesterone. In the present studies, $[1,2,6,7$. ${ }^{3} \mathrm{H}$ ]cortisol (Amersham, Arlington Heights, 14 ) was used as the tracer. Assay sensitivity was $20 \mathrm{pg}$ of CORT, and coefficients of variation within and between assays were 0.07 and 0.10 , respectively $(n=8)$.

High resolution autoradiography and morphological analysis. Autoradiography was conducted according to the method of Gerlach and McEwen (1972). Subjects were adrenalectomized, injected subcutaneously $10 \mathrm{hr}$ later with $100 \mu \mathrm{Ci}$ of $\left[{ }^{3} \mathrm{H}\right] \mathrm{CORT}$, and decapitated $2 \mathrm{hr}$ later. Frozen, $6-\mu \mathrm{m}$-thick sections were cut with a cryostat at $-18^{\circ} \mathrm{C}$ and transferred with a fine brush onto emulsion-dipped slides. Slices were taken every $75 \mu \mathrm{m}$ through the hippocampus. Slides were desiccated and stored in the dark at $4^{\circ} \mathrm{C}$ for 12 months before being developed. Slides were then stained with cresyl violet for anatomical reference, using the anatomical criteria of Lorente de No (1934) for identification of hippocampal cell fields.

The number of CORT-concentrating neurons and the number of grains concentrated per neuron were determined in each slice by microscopic examinaton ( $\times 40$ power). After orienting at the center of a particular cell field, the number of neurons within the field of a $400 \times 400 \mu \mathrm{m}$ ocular grid was counted. The average size of neurons was assessed by dividing the number of ocular grids overlapped by cells by the number of cells; average background grain density in neuropil was then determined for an area equivalent to the average neuron size. With this information, we then determined the total number of neurons within view and the total number which concentrated grains at a rate higher than background. Twenty such cells which concentrated CORT were randomly chosen per cell field per slice, and the precise number of grains (above background) was counted.

Distribution of cell area was determined by orienting at the boundary between $\mathrm{CA} 2$ and $\mathrm{CA} 3$ of the hippocampus. Moving through $\mathrm{CA} 3$ from the boundary, the outlines of all cells containing nuclei encountered within the cell layer were traced onto a digitizing tablet (Summagraphics) which had a Megatek vector graphics display unit. The microscope was used in conjunction with a camera lucida drawing tube. The area of each cell was then determined with an Area Program of a PDP 1134 computer (West et al.,
1976). (We thank Joyce Powzyk and Jane Sekulski of the Torsten Wiesel Laboratory for use of this system.) Tracings were made at $\times 100$. One hundred cells per unilateral hippocampal CA 3 cell field per slice were traced. The total length of CA3 center field covered in the course of encountering 100 discrete cells was noted, so that cell area information could be converted to measures per unit length of cell field. Two slices from dorsal hippocampus per animal were analyzed.

With this information, histograms were constructed of occurrences of cells of varying areas. Because larger nuclei are more likely to be sectioned and counted than smaller nuclei, thus introducing a counting error for cells in different area categories, it was necessry to correct for this split nuclei artifact. The correction equation of Abercrombie (1946) was used, after determining the mean diameter of nuclei of cells in each area category. Mean diameters were found not to differ significantly between acute and chronic subjects (data not shown).

Determination of hippocampal volume. Cresyl violet-stained sections of hippocampus were projected $(\times 16)$ onto a digitized screen, and the area of each section was calculated using the computer program described above. Similar determinations were made for the areas of individual cell fields at $\times 40$.

Statistics. Data were analyzed by onc way and two-way analysis of variance followed by Scheffe post hoc tests.

\section{Results}

Prolonged exposure to titers of CORT in the high physiological range seen during stress reduced the CORT-R number in the hippocampus, in agreement with previous reports (Sapolsky et al., 1984c). Furthermore, there appeared to be a limit to the extent of down-regulation possible, as acute ( 2 weeks) and chronic ( 3 months) subjects showed comparable decreases in CORT-Rs (Fig. 1). Approximately $55 \%$ reductions were observed. We have previously shown no change in affinity of the receptor with such treatment (Sapolsky et al., 1984C).

We next examined whether CORT-R concentrations recovered to control levels following the cessation of CORT treatment (Fig. 1). The substantial declines in CORT-R number in acute subjects had been reversed during 1 week of recovery. Receptor concentrations were then comparable to those of control rats and did not change thereafter. In contrast, chronic subjects showed no evidence of recovery of CORT-Rs and had significant depletions of receptors 4 months after the end of treatment.

We then examined the patterns of CORT-Rs in the hippocampus with high resolution autoradiography. Representative autoradiograms of the CA3 cell field for control, acute, chronic, and aged subjects are presented (Fig. 2, $A$ to $D$ ). We found differences in the cellular bases of the CORT R depletions between acute and chronic subjects which could explain the seeming irreversibility of the receptor loss in the latter group. Specifically, acute subjects had a reduction in the number of CORT-Rs per cell, without a change in the total number of cells. Chronic subjects, in contrast, had a loss of both receptors per cell, and of the steroid-concentrating cclls.

Neuron loss was concentrated in the CA3 cell field (Table II). Acute and control subjects had an equivalent number of cells per unit cell field. Chronic subjects, however, had a significant reduction in the total number of cells. Cells which did not bind CORT did not change in number. Rather, the loss of cells was entirely attributable to a loss in the number of steroid-concentrating cells. No such change occurred in acute subjects. In both acute and chronic animals, cells that concentrated steroid above background accumulated significantly fewer grains, indicating decreased numbers of receptors per cell.

A somewhat different pattern was found in other parts of the hippocampus. In the CA1 cell field, for example (Table II), acute and chronic subjects did not differ trom each other. Neither had a loss in the total number of cells per unit length of cell field. Both had a significant reduction in the number of specifically labeled cells and an equivalent increase in the number of unlabeled cells, indicating that the CORT treatment had down-regulated CORT-R number in many cells to background concentrations. Both groups had significant reductions in the number of grains per labeled cell. 
Figure 1. Maximal binding capacity (in femtomoles of $\left[{ }^{3} \mathrm{H}\right]$ dexamethasone bound per milligram of cytosolic protein) of hippocampi of control, acute, and chronic subjects. Acute subjects were injected subcutaneously daily with 5 $\mathrm{mg}$ of CORT for 2 weeks, and chronic subjects were injected daily for 3 months. Subjects were then allowed to recover from such treatment; four subjects from each group were culled at each time point during the recovery period for receptor assay. Both acute and chronic subjects had significantly diminished binding capacity, relative to controls, at the beginning of the recovery period $(0.01$ level of significance, Scheffe test following two-way analysis of variance). Acute subjects did not differ from controls thereafter, whereas chronic subjects presented equivalently significant depletions of binding capacity throughout the remainder of the recovery period.

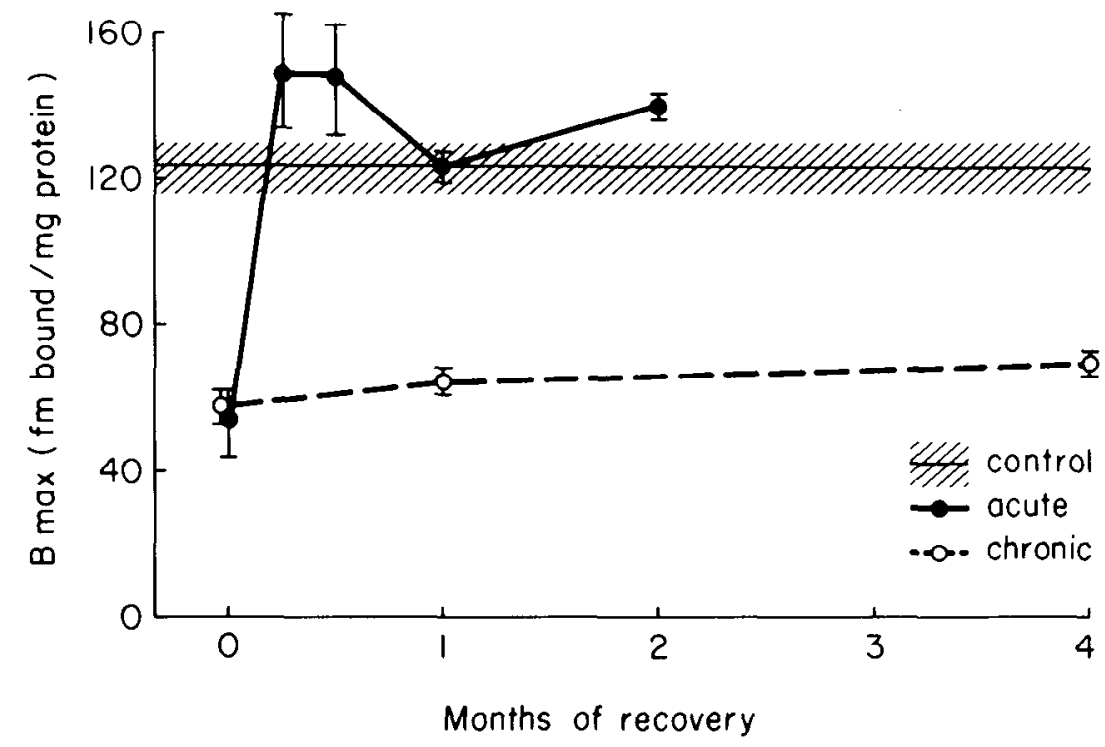

inferred from increased uptake of $\left[{ }^{3} \mathrm{H}\right]$ dexamethasone in vivo (Sapolsky et al., 1983a). The neuronal loss and glial hyperplasia in the aged hippocampus are well demonstrated in Figures 2 and 3, where the morphologic and size characteristics of the large cells which are lost are those of neurons, whereas the small, darkly staining cells whose numbers increase resemble dark glia.

The aging hippocampus also undergoes a progressive loss of CORT-Rs (Angelucci et al., 1980; Sapolsky et al., 1983a), a decline which eventuates in functional impairments in the adrenocortical stress response (Sapolsky et al., 1984b). This loss is limited to neuronal CORT-Rs (in contrast to the inferred increased numbers of glial CORT-Rs; Sapolsky et al., 1983a) and is most pronounced in the CA3 cell field (Sapolsky et al., 1984a). We have previously demonstrated that the neurons which are lost with age in the hippocampus include those containing CORT-Rs. This cell loss accounts for the receptor loss as well as its relative pharmacological intractability to trcatments designed to reverse receptor loss (Sapol sky et al., 1984a).

We hypothesized that the loss of neurons and of their CORT-Rs is due to the cumulative exposure to CORT over the animal's lifespan. This is suggested by the aforementioned vulnerability of neurons containing CORT-Rs. Furthermore, pharmacologic dosages of glucocorticoids destroy hippocampal neurons (Aus Der Muhlen and Ockenfels, 1969). Finally, basal CORT titers rise progressively with age (Landfield et al., 1978; Tang and Phillips, 1978; Sapolsky et al., 1983b; De Kosky et al., 1984); adrenalectomy at middle-age prevents the age-related loss of hippocampal neurons (Landfield et al., 1981a).

In the present study, we have tested the hypothesized linkage between corticosterone and cell loss, examining whether sustained exposure to high physiological titers of CORT produces changes similar to those seen during aging; i.e., prolonged CORT-R losses, loss of receptor-bearing neurons, and glial hypertrophy in those regions of neuron loss. We found that 2-week exposure to CORT was not an appropriate model for aging because the effects were reversible. CORT-R number was markedly reduced in such acutely treated rats (involving reductions in total cellular receptor pools, in addition to cytosolic concentrations, and not due to residual contamination with injected steroids; Sapolsky et al., 1984c). However, within a week after the end of CORT treatment, the concentration of receptors recovered to normal, and the receptor loss was entirely attributable to a loss of receptors per cell, as shown by the decreased numbers of grains per cell in autoradiograms. The decreased numbers of labeled cells and the equivalent increase in unlabeled ones indicates that in some parts of the hippocampus, down-regulation reduced binding to background levels. This rapid 

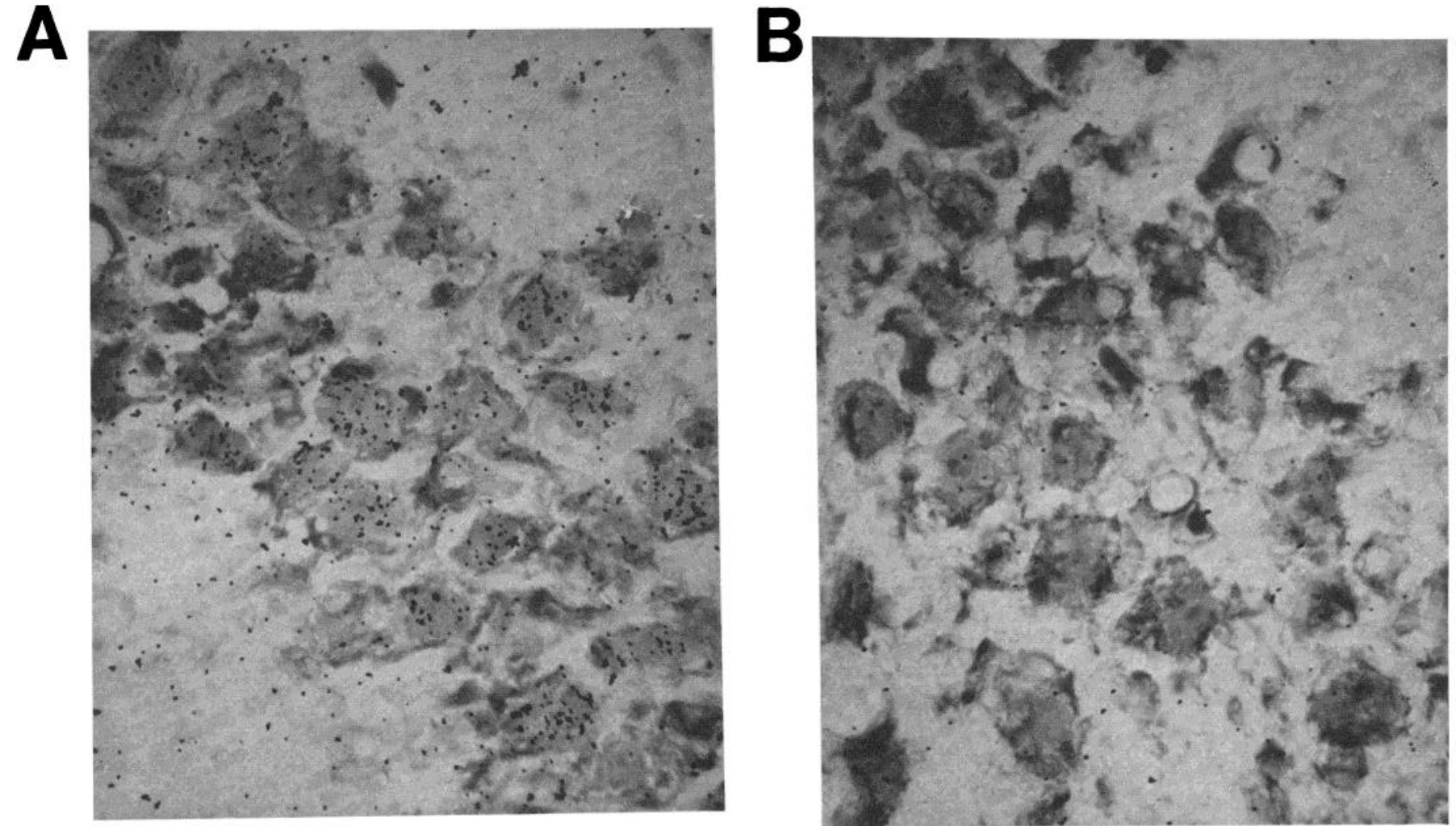
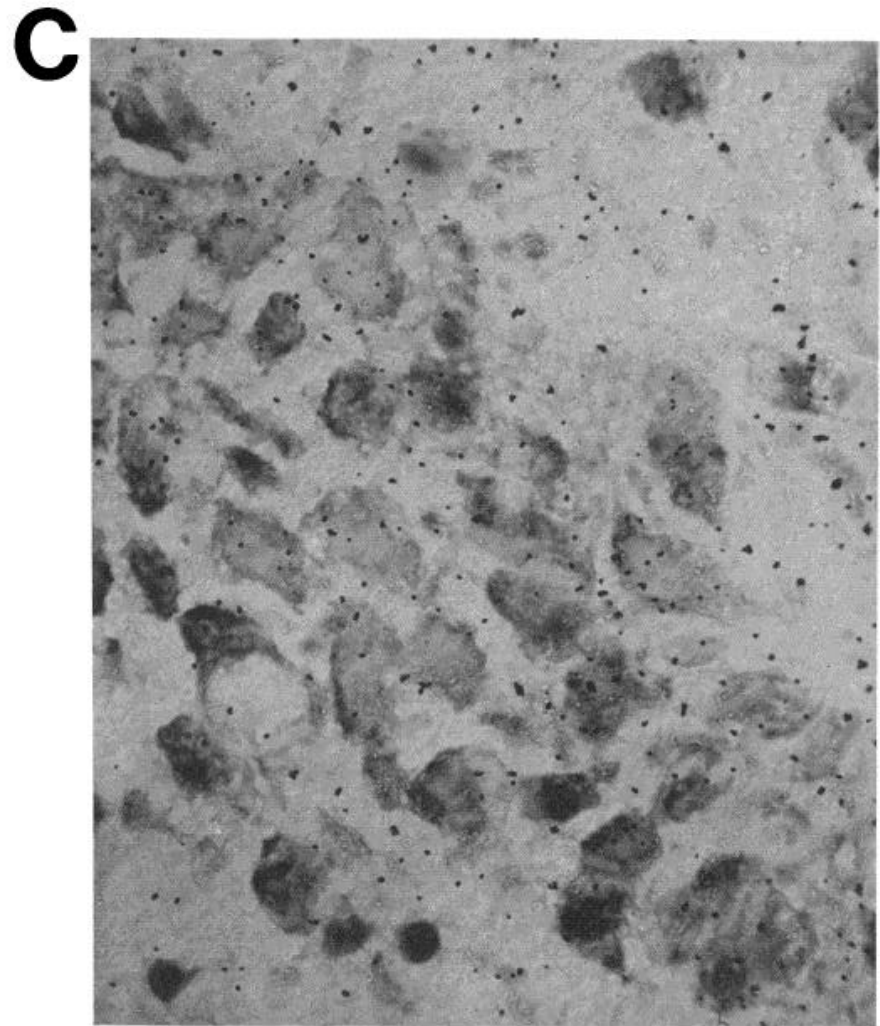

D

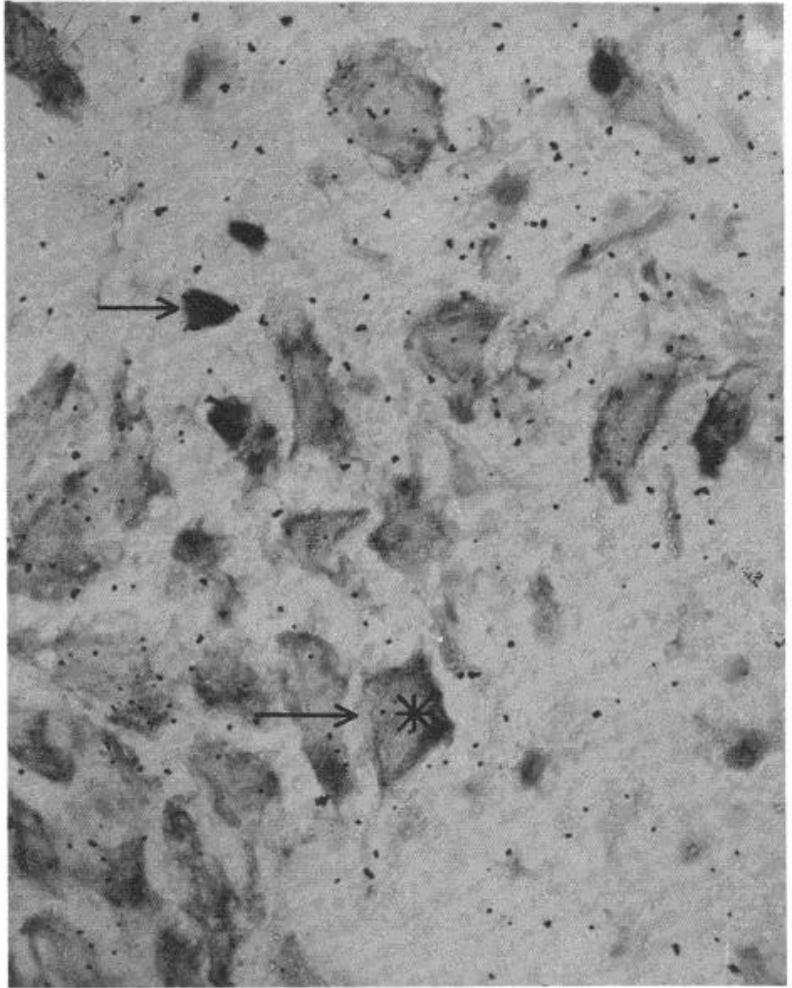

Figure 2. Representative photomicrographs of autoradiograms of the CA3a pyramidal cell region of hippocampus in control $(A)$, acute $(B)$, chronic $(C)$, and aged $(D)$ subjects. The upper arrow in $D$ indicates a representative cell of the 0 - to $70-\mu \mathrm{m}^{2}$ size class; the arrow pointing to the asterisk indicates a representative cell of the 140 - to $280-\mu \mathrm{m}^{2}$ size class. Magnification $\times 400$. 
TABLE \|

Effects of CORT treatment on the numbers and CORT-binding characteristics of hippocampal cells in areas CA3 and CA1

Total cell number indicates the number of cells within a field overlapped by an ocular grid at $\times 40$ power. Number of cells labeled indicates the number concentrating CORT above background. Number of grains/labeled cell involves analysis only of cells concentrating CORT above background. For each group, $n=3$. Values are the mean $\pm \mathrm{SE}$. Clusters of grains were estimated as ranging from two to four individual grains. See the text for more detailed methods. Acute subjects were treated daily with $5 \mathrm{mg}$ of CORT for 2 weeks; Chronic subjects were similarly treated or 3 months.

\begin{tabular}{|c|c|c|c|}
\hline Area & Control & Acute & Chronic \\
\hline \multicolumn{4}{|l|}{ CA3 } \\
\hline Total cell number & $69 \pm 3$ & $67 \pm 14$ & $52 \pm 4^{a}$ \\
\hline Number of cells labeled & $25 \pm 3(36 \%)^{b}$ & $18 \pm 5(25 \%)$ & $8 \pm 1(13 \%)^{c}$ \\
\hline Number grains/labeled cell & $9.9 \pm 1.5$ & $6.3 \pm 0.5^{a}$ & $4.5 \pm 2^{a}$ \\
\hline \multicolumn{4}{|l|}{$\mathrm{CA} 1$} \\
\hline Total cell number & $52 \pm 4$ & $53 \pm 1$ & $48 \pm 1$ \\
\hline Number grains/labeled cell & $9.6 \pm 1$ & $4.8 \pm 1^{a}$ & $3.1 \pm 1^{a}$ \\
\hline
\end{tabular}

${ }^{a} p<0.05$ (two-tailed Scheffe comparison of treated groups with controls after one-way analysis of variance).

${ }^{b}$ Numbers in parentheses, percentage of total cells which were labeled.

${ }^{c} p<0.01$ (two-tailed Scheffe comparison of treated groups with controls after one-way analysis of variance).

\section{TABLE ॥I}

Influence of acute and chronic CORT treatments on the length and volume of hippocampus and individual hippocampal cell fields

For each treatment group, $n=3$. For area determinations, three slices were measured per subject. The anterior coronal sections were taken from a range of 4.3 to $4.6 \mathrm{~mm}$ anterior of lambda suture (dorsal-ventral coordinate of lambda set equal to bregma). The medial sections and those for the determination of individual cell field areas were taken from a range of 3.4 to $4.1 \mathrm{~mm}$ anterior of lambda. The posterior sections were taken from a range of 1.1 to $2.5 \mathrm{~mm}$ anterior of lambda. No significant differences occurred between acute and chronic subjects ( $t$ test).

\begin{tabular}{lcc}
\hline & Acute & Chronic \\
\hline $\begin{array}{l}\text { Anterior/posterior extent of } \\
\text { hippocampus }(\mathrm{mm})\end{array}$ & $3.72 \pm 0.15$ & $3.68 \pm 0.11$ \\
Area of coronal sections of & & \\
$\quad$ hippocampus $\left(\mu \mathrm{m}^{2}\right)$ & & \\
$\quad$ Anterior & $5.6 \pm 0.8$ & $5.9 \pm 0.7$ \\
$\quad$ Medial & $7.7 \pm 0.3$ & $8.5 \pm 0.3$ \\
$\quad \begin{array}{l}\text { Posterior } \\
\text { Area of individual hippocam- }\end{array}$ & $14.4 \pm 1.8$ & $11.9 \pm 1.0$ \\
$\quad$ pal cell fields, in coro- & & \\
$\quad$ nal section $\left(\mu \mathrm{m}^{2}\right)$ & & \\
CA3 & $0.203 \pm 0.039$ & $0.244 \pm 0.047$ \\
Dentate gyrus & $0.350 \pm 0.028$ & $0.397 \pm 0.059$ \\
\hline
\end{tabular}

and reversible form of receptor autoregulation probably represents altered rates of receptor synthesis or degradation (Tornello et al., 1982; Felt et al., 1984).

Prolonged exposure to CORT for 3 months, however, was an appropriate model for aging. Down-regulation of hippocampal CORTRs occurred (to an extent equivalent to that seen in acute subjects, a previously noted "floor effect" (Sapolsky et al., 1984c)), and no recovery of receptor concentration was noted 4 months after the end of CORT treatment. Of prime importance, this persistent receptor loss appears due to a similar cellular mechanism that accounts for the receptor loss in aged rats. In both cases, there were decreased numbers of steroid-concentrating cells, as well as the decreased numbers of receptors per cell seen in all experimental groups. The cell loss was observed in the CA3 cell field but not CA1 in chronic subjects (Table II), and in CA3 and CA1 of aged subjects, but not CA4 (Sapolsky et al., 1984a). We have concluded that the decreased density of cells observed in these regions represents absolute decreases in the total numbers of cells for a number of reasons. First, the overall volume of the hippocampus and the relevant cell fields does not increase in chronic subjects. Second, were the decreased density due to subtly increased volume and subsequent dilution of cells, a decrease would be noted in all cell fields and in all cell sizes. This is not the case. Instead, chronic subjects have selective losses of large hippocampal cells, of similar appearance and size to the neurons lost in the aged hippocampus (Landfield et al., 1977, 1981a; Brizzee and Ordy, 1979). Whereas it is conceivable, although unlikely, that there is a loss of smaller neurons coupled with shrinking of larger ones, the most parsimonious conclusion is that chronic subjects have losses in the same size class of neurons as do aged rats. In addition, chronic subjects have increases in the numbers of small cells, which have staining characteristics and size similar to those of the dark glia whose numbers increase in the aged hippocampus (Ling and Leblond, 1973; Vaughan and Peters, 1974; Landfield et al., 1981b). Such invasive
Figure 3. Histograms of the distribution of cell body sizes in the CA3 pyramidal cell region of hippocampi of control, acute, chronic, and aged subjects. The area of all cell bodies in the first $200 \mu \mathrm{m}$ of the CA3 region (moving from the CA2) CA3a boundary) containing nuclei was determined as described under "Materials and Methods." Cell body areas were then grouped into the categories of 0 to 70,70 to 140,140 to 210,210 to 280 , and $>280 \mu \mathrm{m}^{2}$ of area. Values are mean $\pm \mathrm{SE}, n=3$ per experimental group. *, significantly greater number of cells, relative to controls, at 0.05 level of significance; and, significantly fewer cells, relative to controls, at 0.05 and 0.01 levels of significance, respectively (Scheffe test following two-way analysis of variance).
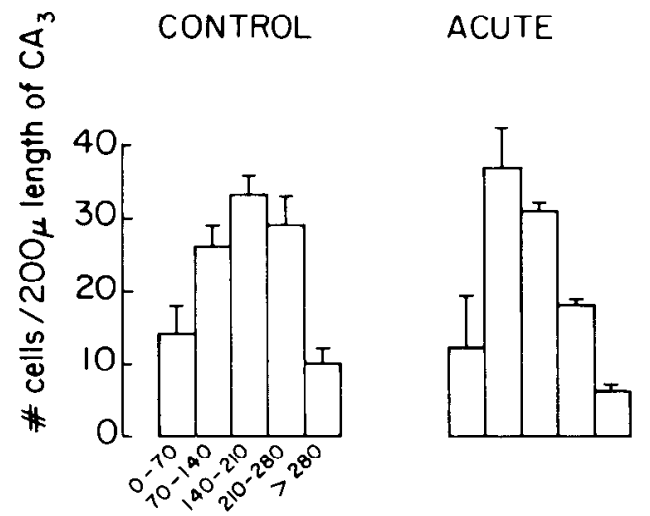

AGED

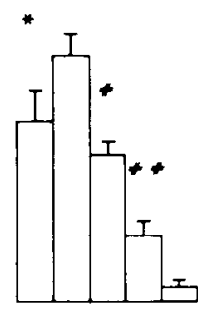


and clustered glia are typical markers of neuronal damage or death, both during aging and following brain injury (Wisniewski and Terry, 1973; Scheibel and Scheibel, 1975).

In summary, striking similarities occur between hippocampi of aged rats and those of rats exposed to prolonged and elevated titers of CORT. In addition to loss of receptors per cell (as was also seen in acute subjects), both display persistent depletions of CORTRs due to loss of CORT-concentrating cells (in contrast to acute subjects). This cellular loss is most dramatic in the CA3 region, and the cells that are lost are of similar size. Finally, both show the increased numbers of darkly staining glia typically found after brain tissue damage. These findings support and extend the previous suggestions of Landfield et al. (1981a), that the loss of hippocampal neurons with age is due to cumulative exposure to increasingly elevated titers of CORT. In the following paper (Sapolsky, 1985), we examine the effects of CORT on kainic acid- or 3-acetylpyridineinduced hippocampal neuronal loss in order to obtain insights into the mechanisms underlying CORT neurotoxicity.

\section{References}

Abercrombie, M. (1946) Estimation of nuclear populations from microtome sections. Anat. Rec. 94: 239-247.

Angelucci, L., P. Valeri, E. Grossi, H. Veldhuis, B. Bohus, and E. De Kloet (1980), Involvement of hippocampal corticosterone receptors in behavioral phenomena. In Progress in Psychoneuroendocrinology, F. Brambilla, G. Racagani, and D. de Wied, eds., pp. 177-185, Elsevier Biomedical Press, Arnsterdam.

Aus Der Muhlen, $\mathrm{K}_{\text {., }}$ and $\mathrm{H}$. Ockenfels (1969) Morphologische veranderungen im diencephalon und telencephalon nach storungen des regelkreises adenohypophyse-nebennierenrinde. III. Ergebnisse beim meerschweinchen nach verabreichung von cortison und hydrocortison. $Z$. Zellforsch. 93: 126-141

Brizzee, K., and J. Ordy (1979) Age pigments, cell loss and hippocampal function. Mech. Ageing Dev. 9: 143-162.

De Kosky, S., S. Scheff, and C. Cotman (1984) Elevated corticosterone levels: A possible cause of reduced axon sprouting in aged animals. Neuroendocrinology 38: 33-38.

Felt B., R. Sapolsky, and B. McEwen (1984) Regulation of hippocampal corticosterone receptors by a vasopressin analogue. Peptides, 5: 12251227.

Gerlach, J., and B. McEwen (1972) Rat brain binds adrenal steroid hormone: Radioautography of hippocampus with corticosterone. Science 175: 11331136.

Krey L., K. Lu, W. Butler, J. Hotchkiss, F. Piva, and E. Knobil (1975) Surgical disconnection of the medial basal hypothalamus and pituitary function in the rhesus monkey. II. GH and cortisol secretion. Endocrinology 96: 10881096.

Landfield, P., G. Rose, L. Sandles, T. Wohlstadter, and G. Lynch (1977) Patterns of astroglial hypertrophy and neuronal degeneration in the hippocampus of aged, memory-deficient rats. J. Geront. 32: 3-12.
Landfield, P., J. Waymire, and G. Lynch (1978) Hippocampal aging and adrenocorticoids: Quantitative correlations. Science 202: 1098-1102.

Landfield, P., R. Baskin, and T. Pitler (1981a) Brain aging correlates: Retardation by hormonal-pharmacological treatments. Science 214: 581.584.

Landfield, P., L. Braun, T. Pitler, J. Lindsey, and G. Lynch (1981b) Hippocampal aging in rats. A morphometric study of multiple variables in semithin sections. Neurobiol. Aging 2: 265-275.

Ling, E., and C. Leblond (1973) Investigation of glial cells in semithin sections. II. Variations with age in the numbers of the various glial cell types in rat cortex and corpus callosum. J. Comp. Neurol. 149: 73-82.

Lorente de No, R. (1934) Studies on the structure of the cerebral cortex. II. Continuation of the study of the ammonic system. J. Psychol. Neurol. 46: 113-177.

Lowry, O. H., N. J. Rosebrough, A. L. Farr, and R. J. Randall (1951) Protein measurement with the Folin phenol reagent. J. Biol. Chem. 193: 265-275.

Sapolsky, R., L. Krey, and B. McEwen (1983a) Corticosterone receptors decline in a site-specific manner in the aged rat brain. Brain Res. 289: 235-240.

Sapolsky, R., L. Krey, and B. McEwen (1983b) The adrenocortical stressresponse in the aged male rat: Impairment of recovery from stress. Exp. Gerontol. 18: 55 . 64

Sapolsky, R. M. (1985) Mechanism for glucocorticoid toxicity in the hippocampus: Increased neuronal vulnerability to metabolic insults. J. Neurosci. 5: 1227-1231.

Sapolsky, R., L. Krey, B. McEwen, and T. Rainbow (1984a) Do vasopressinrelated peptides induce hippocampal corticosterone receptors? Implications tor aging. J. Neurosci. 4: 1479-1485.

Sapolsky, R., L. Krey, and B. McEwen (1984b) Glucocorticoid-sensitive hippocampal neurons are involved in terminating the adrenocortical stressresponse. Proc. Nat. Acad. Sci. U. S. A. 81: 6174-6177.

Sapolsky, R., L. Krey, and B. McEwen (1984c) Stress down-regulates corticosterone receptors in a site-specific manner in the brain. Fndocrinology 114: $287-292$

Scatchard, G. (1949) The attractions of proteins for smaller molecules and ions. Ann. N. Y. Acad. Sci. 51:660-703.

Scheibel, M., and A. Scheibel (1975) Structural changes in the aging brain. In Aging, H. Brody, D. Harmon, and J. Ordy, eds., Vol. 1, pp. 11-37, Raven Press, New York.

Tang, G., and R. Phillips (1978) Some age-related changes in pituitaryadrenal function in the male laboratory rat. J. Gerontol. 33: 377-382.

Tornello, S., E. Orti, A. DeNicola, T. Rainbow, and B. McEwen (1982) Regulation of glucocorticoid receptor in the brain by corticosterone treatment of adrenalectomized rats. Neuroendocrinology 35: 411-419.

Vaughan, D., and A. Peters (1974) Neuroglial cells in the cerebral cortex of rats from young adulthood to old age: An electron microscope study. J. Neurocytol. 3: 405-439.

Veldhuis, H., and E. de Kloet (1982) Vasopressin-related peptides increase the hippocampal corticosterone receptor capacity of diabetes insipidus (Brattleboro) rats. Endocrinology 110: 153-157.

West, M., G. Danscher, and S. Laurberg (1976) A determination of the volumes of the rat hippocampal subtields. Soc. Neurosci. Abstr. 2: 214.

Wisniewski, H., and R. Terry (1973) Morphology of the aging brain, human and animal. Prog. Brain Res. 40: 167-186. 